\title{
THE INFLUENCE OF SOME FACTORS OF COMPETITIVENESS ON BUSINESS RISKS
}

\author{
Jan DVORSKY (D) ${ }^{*}$, Tomas KLIESTIK (D) ${ }^{2}$, Martin CEPEL (D) 3 , \\ Zdenek STRNAD (iD 4 \\ ${ }^{1}$ Department of Business Administration, Faculty of Economics and Management, \\ Tomas Bata University in Zlin, Zlin, Czech Republic \\ ${ }^{2}$ Faculty of Operation and Economics of Transport and Communications, \\ University of Žilina, Žilina, Slovak Republic \\ ${ }^{3}$ Faculty of Economics and Business, Paneuropean University in Bratislava, Bratislava, Slovak Republic \\ ${ }^{4}$ Faculty of Economics, University of South Bohemia in České Budějovice, \\ České Budějovice, Czech Republic
}

Received 24 April 2020; accepted 19 August 2020

\begin{abstract}
The impact of significant competition factors on the riskiness of business risk in the SMEs sector in the Czech Republic and Slovak Republic. The empirical research was constructed on the basis a questionnaire. The attitudes from 641 entrepreneurs from two countries were collected during the year 2018. The statistical hypotheses were evaluated using quantitative methods. The multiple linear regression models were used to evaluate the impact of the competitive environment and of the narrow business environment on the perception of the riskiness of business risk according to entrepreneurs. The conclusions ofthe research showed an interesting finding. The authors found that the competitive environment, as well as the narrower business environment, affects the perception of the riskiness of business risk. It has also been shown that my customers accept the prices of my products and services. This is the most important indicator of a competitive environment. The most important indicator of a narrower business environment is that my customers support me in doing business. The authors believe that the article has brought several interesting findings and new incentives for the further research and discussion regarding to the perception of enterprise risk not only in the selected countries this research.
\end{abstract}

Keywords: small and medium enterprise, competitiveness, business environment, business risks, narrower business environment, competitive environment, quality.

JEL Classification: M41, C83, L20.

\section{Introduction}

The rapid technological change and market globalization (Ahmedova, 2015; Hudakova et al., 2018), ultracompetitive business environment in an international context (Liňán et al.,

*Corresponding author. E-mail: j1dvorsky@utb.cz 
2019), the quality of the business environment and the impact of its individual factors within national economies (Bozic \& Rajh, 2016; Artistovnik \& Obadic, 2015; Kitching et al., 2015; Dragnic, 2014), and intensive need of innovative activities have a great impact on the business competitive environment of small and medium-sized enterprises (SMEs), because they bring new challenges but also threats to these companies (Kolupaieva et al., 2019). Pérez-Luño et al. (2014) define in general two types of the orientation of SMEs: entrepreneurial orientation and market orientation. Companies that prefer entrepreneurial orientation are focused on the implementation of individual components of entrepreneurial orientation (innovativeness, proactivity, risk-taking, competitive aggressiveness, and autonomy according to Lumpkin and Dess (1996)). Market-oriented SMEs focused on meeting new customer needs by gradually changing products to create superior value and build long-term relationships with them (Dvoulety \& Orel, 2020; Dvorsky et al., 2020; Khan et al., 2019). SMEs have many specific characteristics that significantly determine their approach to business activity and affect their performance and competitiveness. These businesses are generally managed by the business owner. The individual characteristics of the entrepreneur are important for the management of the company and its market survival (Nikolic et al., 2019; Ključnikov et al., 2019; Kozubíková et al., 2015) and play an important role in SME risk management (Falkner \& Hiebl, 2015). Because of their size, SMEs are very flexible and adaptable in responding to current market needs (Konstantopoulou et al., 2019), independent and based on individual creativity (Mustafa et al., 2019). These companies are very diverse in size and product orientation and are often oriented towards serving local niches or developing narrow specializations (Singh et al., 2010). On the other hand, SMEs are very sensitive to economic change (Hvolkova et al., 2019), suffer from a lack of capital and limited access to external capital (Rahman et al., 2017, 2018; Kersten et al., 2017; Baños-Caballero et al., 2016; Irwin \& Scott, 2010 and many others) have insufficient knowledge of business risk management, especially financial risk (Belas et al., 2018a) and, as a result, less quality management of human resources (Remi, 2018) and lack of financial resources are facing a lack of quality and talented people in the company (Pisar \& Bilkova, 2019). In this context, Ravselj and Aristovnik (2018) emphasize the aspect of administrative and tax barriers in their activities, because they cannot hire qualified professionals or outsource these services due to their low financial performance. Companies are conducted in uncertain conditions that can lead to unpredictable and random results (Lazányi et al., 2018). As SMEs operate in an intensely competitive environment, it is important to explore the issue of competitiveness in the context of business risks. In this study, it is present the results of the research of the dependence of the risk assessment of the business environment in the SME sector on the intensity of action of defined types of competitiveness. The originality of the research is to identify and quantify the significant factors that create a competitive environment and quantify the intensity of this dependency based on the attitudes of entrepreneurs. The structure of the article is as follows. The introductory part presents the results of scientific studies in the field of competition and business risks. In the next part of the article, the aim of the research, methodology and data are used. The research results and discussion section presents the research results and discussion on these results. Subsequently, the basic results of the research and its limits are presented. 


\section{Theoretical part}

Enterprise competitiveness is the cornerstone of a market economy. This is a situation where a large number of manufacturers operate on the market for goods and services, offering the same or similar products and services to customers. Increasing intensity of competition creates enormous pressure to increase the quality of products and services and at the same time to decrease prices of offered products, which creates strong pressure to manage performance and risks in SMEs. Enterprise competitiveness should be seen as a multidimensional and heterogeneous process (Ceptureanu, 2015), which is the result of the action of numerous external factors such as direct competitors, customers, suppliers and internal factors (management, financial and human resources). Highly dynamic nature at times and determine the competitive position of a company compared to its competitors (Ahmedova, 2015). Enterprise competitiveness can manifest itself in the following areas, such as product quality competitiveness, price competition, competition in management and production processes (Taçoğlu et al., 2019). The level of competitiveness of the company is decisively influenced by two main factors of competitive environment: customers and competitors (Ceptureanu, 2015). At the same time, the level of enterprise competitiveness influences the perception of the riskiness of the business environment. Several authors deal with this issue. Yang et al. (2018) stress the importance of ERM (Enterprise Risk Management) in the context of strengthening the competitiveness of SMEs. The ERM concept focuses on a comprehensive approach to SME risk management in the context of increasing their performance and competitiveness. According to the authors, the ERM concept enables SMEs to reduce financial costs, avoid profit volatility and support innovative business activities. It also allows the company to remain variable and respond to economic threats and brings competitive advantages. SMEs can increase their competitiveness through multiple approaches. ERM helps reduce the exposure of risk factors in a company, allowing them to be more stable in a competitive environment. Competitiveness can be increased by differentiating its product or service, reducing the various costs of materials or supplying the production of goods or services is increased and companies can offer cheaper products. That is, ERM provides the company with high productivity, which leads to increased competitiveness. Similarly, Hudakova et al. (2018) stress the importance of risk management in the SME sector. According to the authors, high-quality risk management enables SMEs to make important decisions in the context of the growth of their performance and competitiveness and correctly set the prices of the offered goods and services. Their study conducted in Slovakia revealed 4 of the most significant risk groups faced by SMEs: market risks, financial risks, economic risks, personnel risks. According to the authors, the most common market risks in Slovakia include intense competition, loss of customers, market stagnation and unreliable suppliers. Similar results are reported by Lazányi et al. (2018), who conducted research in the conditions of Czech and Slovak SMEs. According to authors for Czech and Slovak SMEs, the most significant among business risks is market risk. Virglerová et al. (2016) emphasize the importance of financial risk in the context of SME management and defines six key areas that affect the business of Czech SMEs as follows: access to finance, excessive government regulation, high competition High Manufacturing Costs. The research by Belas et al. (2018b) underlines the importance 
of non-economic factors such as education and the family environment in the financial risk management process. Rostamkalaei and Freel (2015) and Lewandowska and Stopa (2019) investigated the financial aspects of SME growth. According to the authors, the growth of the company and innovation of products and services or processes pose additional risks to SMEs. Moreover, more risk strategies associated with entering a new market and production of new goods and services are associated with a higher interest rate, which has a negative impact on the efficiency of companies. Delić et al. (2016) and Gavurova et al. (2017) admit the importance of financial literacy in the financial risk management process. According to the authors of financial literature, the impact of opposing information helps business owners make more informed decisions about external sources of financing, which ultimately lead to better business results and increased competitiveness. Vargas-Hernández et al. (2016) depict the importance of standards of internal control of SMEs on their competitiveness. SMEs in which there are no internal control systems undermine their competitiveness since such deficiency leads to higher operating costs, and lack of reliable and verified information for timely decisionmaking in conditions of intense competition. A number of findings in the field justify the conclusion that financial risk is extremely important in a crisis situation, while the importance of market risk is increasing in the standard economic environment. Several authors examine aspects of the internationalization of SMEs' activities, which represent a potential way to increase the performance and competitiveness of SMEs and to ensure the sustainability of their business. According to Toulová et al. (2016), growing competition on the domestic market, along with other factors such as globalization and new technologies, are pushing companies to enter foreign markets. These authors examined similarities and differences in the approach of SMEs in Slovakia, Poland, the Czech Republic, Germany, and Austria to manage risks associated with the internationalization of SMEs. According to SME authors, they are not adequately equipped with human and financial resources for foreign expansion and must focus on managing the risks associated with the internationalization of their business activities. In conclusion, the study states that only a small percentage of interviewed SMEs from each country apply sophisticated risk management analysis methods. "Risks by enterprises from different countries are perceived differently, depending on the environment from which they come and the environment they want to enter". In this context, an interesting approach is presented by Bozic and Rajh (2016). The authors state that there are many barriers to innovation performance of SMEs, which may be an opportunity to enter new markets. "However, SMEs often do not have all the necessary experience and capabilities to compete on the international market". Sipa (2017) researched innovations in small enterprises with different levels of competitiveness and innovativeness in Poland. The author states that if SMEs want to achieve a stable market position, it is necessary to be competitive in many areas, for example, in strategy, IT, knowledge, skills, organizational culture, but especially in the field of innovation, because these bring modernization of products and services and process optimization. Companies with low levels of competitiveness and innovation have become more interested in improving working conditions and see high priority in achieving short-term goals (reducing costs and prices), while not focusing on achieving long-term goals (improving product and service quality through innovation). "Stable market companies are involved in raising the share in sales on the current market, 
while less successful companies want to keep their market share. Innovative and stable enterprises demonstrate consistency in adhering to the goals that they are trying to achieve through innovation while reducing costs is not their main goal. They want to increase the share of sales in the current market and introduce new products and services with the help of innovations". In this regard, Werner et al. (2017) stress that innovative SMEs are characterized by a flexible organizational structure, the support of their skilled human resources and the desire to cooperate. According to the authors, the organizational culture is indirectly related to the performance of a small company and is completely mediated by entrepreneurial orientation. Small enterprisers can increase their financial performance within a corporation focused on adhocracy and market cultures, encouraging innovative and active behaviour (Khedhaouria et al., 2020). The relationship with customers is crucial for the growth of competitiveness of SMEs. Grimsdottir and Edvardsson (2018) report that communicating of SMEs with customers is extremely important as a source of new knowledge. Customer demand for new products and services and the willingness of employees and managers of SMEs to meet these requests play a major role in this process. Ungerman et al. (2018) stress the importance of marketing innovation in the process of increasing the competitiveness of a company. According to the authors, for businesses to become more competitive and improve their performance, they must constantly develop new products. In this regard, Taçoğlu et al. (2019) stress the importance of long-term relationships of SMEs with their customers, with an emphasis on their differentiation and in order to provide high quality products and services, leading to a higher degree of client loyalty. A higher level of client satisfaction and loyalty lead to an additional purchase of products (Belas \& Gabcova, 2016). Mafini and Muposhi (2017) examined the relationships between SMEs and their suppliers. According to the author, the existence of long-term relationships between SMEs and their suppliers does not automatically lead to better risk management in this area. The conclusions of the study also improve if the appropriate link between SMEs and their suppliers is strengthened on the basis of sound perception and correct assessment of the position of suppliers without interfering with their activities. Falkner and Hiebl (2015) describe some of the risks that SMEs may face in relation to their suppliers. SMEs may run the risk of higher prices for raw materials compared to large companies. At the same time, the authors draw attention to the fact that, in order to meet customer needs, SMEs have to offer a wide range of goods and services, which increases their dependence on suppliers. This can make them more dependent on business credit leading to an enormous indebtedness of the company with the possibility of future bankruptcy. At the same time, this may mean that there is too much dependence on a particular supplier. Difficulties with a particular supplier who has a strong position can lead to production disruptions, which is another element of the risk associated with the supplier chain.

\section{Aim, methodology, data and methods}

The main aim of the article is to present new scientific knowledge in the field of researching the impact of significant competition factors on the perception of business risk in the SME sector. In regards to the defined aim, the research was conducted with enterprises operating 
in the SME segment in the Czech Republic (CR) and Slovak Republic (SR). The sample of respondents was 641 SMEs (329 enterprises (51.3\%) from SR a 312 enterprises (48.7\%) from CR). The enterprises were approached in the period from January to December 2018. The method of random choice using the "Randbetween" was applied to select SMEs from the "Albertína" database comprising enterprises in the CR. SMEs from SR were randomly selected from the "Cribis" database. Both databases are containing the most important information about SMEs in CR and SR. The enterprises were approached via email with the structured request to fill out the online questionnaire. The questionnaire was intended for business owners or top management (hereinafter respondent). The questionnaire contained 82 statements. The questionnaire was constructed according to the national language of the entrepreneur.

The link to the Slovak questionnaire is: https://docs.google.com/forms/d/1_H7WSPiVJ ZkEXdQx3VlGV0iJ_4ppDKRIQMXL6F8Vn-4/edit

The link to the Czech questionnaire is: https://docs.google.com/forms/d/e/ 1FAIpQLSdTbrl5oKX93-hFY2deUAOYeWHWgI-tBa3zPape_FiJAmI-Dg/viewform

The questionnaire was divided into the following sections: 1 . characteristics of the enterprise - region of enterprise, sector of the economy, size of enterprise and the time period of operating a business; 2 . socio-demographic characteristics of respondents - gender, age and highest attained education level of the entrepreneur; 3 . business environment factors - market and financial factors, political and technological factors, social factors and competitive environment; 4 . business environment quality indicators. The percentage of completed questionnaires that contained positive feedback responses reached approximately $3.7 \%$ (641 out of 17,000 SME from CR and SR). The questions in the questionnaire were randomly assigned. The questionnaire also contained a control question to prevent it from being automatically filled by a computer. The attitudes of respondents were constructed according to a Likert five-point scale: from 1 "totally disagree" to 5 "totally agree" with the statement.

Following the approach by Conorto et al. (2014), individual constructs were defined using the following statements (the independent variables are CF and NBE; the dependent variable is QBE): Competitive environment (CF): CF1: New competitors entering the industry I operate in present an adequate risk; CF2: The level of competition in the industry I operate in is normal; CF3: My customers accept the prices of my products and services; CF4: My suppliers' prices for products and services are adequate. Narrower business environment (NBE) comprises direct competitors, customers, suppliers, and employees: NBE1: My competitors do not present a threat to my business; NBE2: My customers support me in doing business; NBE3: My suppliers intensively support me in doing business; NBE4: My employees intensively help me in achieving business goals. QBE2: The business environment of my country bears adequate risk and enables to start a business.

To fulfil the aim of the article, null statistical hypotheses (NSH) were formulated:

- NSH1: Risk adequacy of new competitors (NSH1a); competition in the business sector (NSH1b); accepting the prices of my customers (NSH1c); adequacy of the prices of my suppliers (NSH1d) is no statistically significant indicator, which determines the competitive environment,

- NSH2: Comprises direct competitors (NSH2a); customers support (NSH2b); suppliers support (NSH2c); and employees (NSH2d) is no statistically significant indicator, which determines to the narrower business environment. 
- NSH3: Competitive environment (NSH3a) and narrower business environment (NSH3b) is no statistically significant factors, which determines the riskiness of business risk in the business environment of the CR and SR.

The multiple linear regression (MLR) was used: 1 . to quantify the relationship between the variables (according to the value of the estimated coefficient of variable); 2 . to identify the most important indicator and factor of the QBE (to verify the NSH1, NHS2, NSH3 and NSH4).The aim of apply LRMs isn't to forecast the values of the dependent variable in research. The LRMs are one of the appropriate statistical methods for factors evaluation because all variables are metrics. The independent variables $\left(C F_{1}, \ldots, N B E_{4}\right)$ must satisfy the assumptions of linearity and a normal distribution of data. The assumption of normality was verified by the descriptive characteristics (skewness and kurtosis). The assumption of normal distribution is acceptable, if the value of the skewness and kurtosis was in interval $\langle-2$; $2>$ (Arnold, 1980). The coefficient correlation (R) was used to verify the dependence between variables. The T-test was used to verify the significance of the estimate coefficients in the regression model (Breslow, 1990). Autocorrelation was not examined for each regression model because the sample data are not time series (Li \& Valliant, 2011). The assumption of homoscedasticity of the errors was verified by Levene's test. This assumption is acceptable, if the Levene's statistics is lower than the critical value (CV = 2.985) (Qin \& Lawless, 1995). The normality distribution of errors is accepted when the p-value of S-W statistics is greater than the level of significance. The authors constructed the following LRMs:

Regression model (RM1):

$$
C F=\beta_{0}+\beta_{1} \times C F_{1}+\beta_{2} \times C F_{2}++\beta_{3} \times C F_{3}++\beta_{4} \times C F_{4}+\varepsilon_{t},
$$

where: $C F$ - the dependent variable (Competitive environment); $\beta_{0}$ - constant; $\beta_{1}, \ldots, \beta_{4}-$ coefficients of independent variables $C F_{i}$; $C F_{i}$ - independent indicators of competitive environment; $\varepsilon_{t}$ - error term.

Regression model (RM2):

$$
N B E=\beta_{0}+\beta_{1} \times N B E_{1}+\beta_{2} \times N B E_{2}++\beta_{3} \times N B E_{3}++\beta_{4} \times N B E_{4}+\varepsilon_{t},
$$

where: $N B E$ - the dependent variable (Narrower business environment); $\beta_{0}$ - constant; $\beta_{1}, \ldots$, $\beta_{4}$ - coefficients of independent variables $N B E_{i} ; N B E_{i}$ - independent indicators of narrower business environment; $\varepsilon_{t}$ - error term.

Regression model with factors (RM3):

$$
Q B E=\beta_{0}+\beta_{1} \times C F+\beta_{2} \times N B E+\varepsilon_{t},
$$

where: $Q B E$ - the dependent variable (Quality of business environment); $\beta_{0}$ - constant; $\beta_{1}$, $\beta_{2}$ - coefficients of independent variables $(C F, F F) ; C F, N B E$ - independent variables $(C F-$ competitive environment, $N B E$ - narrower business environment); $\varepsilon_{t}$ - error term.

The basic regression characteristics are: the coefficient of determination $\left(\mathrm{R}^{2}\right)$, the adjusted coefficient of determination (Adj. $\mathrm{R}^{2}$ ), the multiple coefficient of correlation $(\mathrm{R}), \mathrm{F}$ - test (verified the significance of the whole regression model (Arnold, 1980)), VIF - test (verify 
the presence of multicollinearity in the model). If the p-value of the F-test is more than the level of significance, then it is considered that the regression model is no statistically significant (Stewart, 1987). If the value of the VIF test for the independent variable is less than 5, then it is noted that the coefficient is not affected by multicollinearity (Stewart, 1987). The level of significance when applying the above tests is 0.05 . The results were calculated using the SPSS Statistics.

The structure of the sample according to the other characteristics of respondents was as follows (the Czech Republic (312 SMEs)/Slovak Republic (329 SMEs)): by time period of operating a business (CR/SR): 56/104 (17.9\%/31.6\%) enterprises less than 5 years, 48/78 (15.4\%/23.7\%) enterprises from 6 to 10 years, 208/147 (66.7\%/44.7\%) enterprises more than 10 years; size of business: 258/234 (82.7\%/71.1\%) micro-enterprises (less than 10 employees), $43 / 71$ (13.8\%/21.6\%) small enterprises (from 10 to 49 employees), and 11/24 (3.5\%/7.3\%) medium-sized enterprises (from 50 to 249 employees); highest attained education level of the entrepreneur: 50/10 (16.0\%/3.0\%) high school without diploma, 135/95 (43.3\%/28.9\%) high school with diploma, and 127/224 (40.7\%/68.1\%) university education; gender of entrepreneurs: $236 / 251(75.6 \% / 76.3 \%)$ men, $76 / 78(24.4 \% / 23.7 \%)$ women; the sectors of the economy: 109/122 (34.9\%/37.1\%) service, 73/69 (23.4\%/21.0\%) commercial, 53/51 (17.0\%/15.5\%) manufacturing, 29/39 (9.3\%/3.3\%) construction, 19/11 transportation (6.1\%/11.9\%), 9/20 (2.9\%/6.1\%) agriculture companies, and 49/17 (15.7/5.1\%) other companies.

\section{Results and discussion}

The assumption of the linearity of all variables was confirmed (according to graphical analysis - scatter plots). There are linear trends between variables $\left(Q B E\right.$ and $\left.C F_{1} ; \ldots, N B E_{4}\right)$. Linear trends can be seen in chart analysis (scatter plots). The results of the assumption of normal data distribution are given in Table 1.

Table 1. Verification of the assumptions of RM1 and RM2 (source: own data collection)

\begin{tabular}{|l|l|l|c|c|c|c|}
\hline Type of RM & $\begin{array}{c}\text { The assumption } \\
\text { of regression } \\
\text { analysis }\end{array}$ & $\begin{array}{c}\text { Verification } \\
\text { tool }\end{array}$ & \multicolumn{4}{|l|}{ Independent variables } \\
\hline \multicolumn{2}{|l|}{ Indicators of Factor $-C F$} & $C F_{1}$ & $C F_{2}$ & $C F_{3}$ & $C F_{4}$ \\
\hline \multirow{2}{*}{ RM1 } & AND & Skewness & -0.220 & -0.264 & 1.487 & 0.382 \\
\cline { 4 - 8 } & Kurtosis & -0.892 & -0.943 & -1.192 & -0.916 \\
\hline Indicators of Factor - NBE & & $N B E_{1}$ & $N B E_{2}$ & $N B E_{3}$ & $N B E_{4}$ \\
\hline \multirow{2}{*}{ RM2 } & AND & Skewness & -1.237 & 0.706 & 0.059 & 0.129 \\
\cline { 3 - 7 } & Kurtosis & 0.095 & -0.762 & -0.559 & -0.559 \\
\hline
\end{tabular}

Note: AND - Assumption of Normal Distribution.

The assumption of normal distribution (the values of descriptive characteristics are in the interval from -2 to 2 ). The dependencies between a dependent variable and an independent variable (according to the coefficient of correlation) are summarised in Table 2. 
Table 2. Correlation and SEC according to the selected model (source: own data collection)

\begin{tabular}{|l|l|c|c|c|c|}
\hline $\begin{array}{c}\text { Type of } \\
\text { RM }\end{array}$ & $\begin{array}{c}\text { Correlation and Significance of } \\
\text { the estimate coefficient (SEC) }\end{array}$ & \multicolumn{4}{|c|}{ Independent variables } \\
\hline \multicolumn{2}{|l|}{ Indicators of Factor - CF } & $C F_{1}$ & $C F_{2}$ & $C F_{3}$ & $C F_{4}$ \\
\hline \multirow{2}{*}{ RM1 } & Coefficient of correlation (CC) & 0.221 & 0.163 & 0.270 & 0.160 \\
\cline { 2 - 6 } & SEC (t-test; p-value) & $<0.001$ & 0.452 & $<0.001$ & 0.166 \\
\hline \multirow{2}{*}{ Indicators of Factor - NBE } & $N B E_{1}$ & $N B E_{2}$ & $N B E_{3}$ & $N B E_{4}$ \\
\hline \multirow{2}{*}{ RM2 } & Coefficient of correlation & 0.038 & 0.240 & 0.166 & 0.127 \\
\cline { 2 - 6 } & SEC (t-test; p-value) & 0.936 & $<0.001$ & $<0.001$ & 0.217 \\
\hline
\end{tabular}

Note: CC - Correlation between the independent variable and dependent variables (RM1: CF; RM2: NBE; RM3: QBE).

The correlation between variables showed low or medium-strong values (see Table 2). The estimated coefficient of the independent variable is no statistically significant if the p-value of the student's statistics (t-test) is greater than 0.05 (less than $t$-Stat $=1.934$ ). The results of the statistical significance of the thus designed regression models (RM1, RM2) are presented in Table 3.

Table 3. Regression characteristics of the regression models (source: own data collection)

\begin{tabular}{|c|c|c|c|c|c|}
\hline \multirow{3}{*}{$\begin{array}{l}\text { Regression } \\
\text { characteristics }\end{array}$} & \multicolumn{5}{|c|}{ Type of regression model } \\
\hline & \multicolumn{2}{|c|}{ RM1 } & \multicolumn{2}{|c|}{ RM2 } & \multirow{2}{*}{ RM3 } \\
\hline & $C F_{i}$ to $C F$ & $C F$ to $Q B E$ & $N B E_{i}$ to $N B E$ & $N B E$ to $Q B E$ & \\
\hline $\mathrm{R}$ & 0.326 & 0.301 & 0.261 & 0.218 & 0.351 \\
\hline $\mathrm{R}^{2}$ & 0.106 & 0.090 & 0.068 & 0.047 & 0.123 \\
\hline Adj. $\mathrm{R}^{2}$ & 0.101 & 0.089 & 0.062 & 0.045 & 0.112 \\
\hline F-test (p-value) & $9.82 \mathrm{E}-15$ & $7.84 \mathrm{E}-15$ & $4.06 \mathrm{E}-09$ & $2.74 \mathrm{E}-08$ & $1.09 \mathrm{E}-14$ \\
\hline Type of model & \multicolumn{5}{|l|}{ MLR equation } \\
\hline RM1 & \multicolumn{5}{|c|}{$\begin{array}{l}C F=1.345+0.162 \times C F_{1}+0.035 \times C F_{2}+0.256 \times C F_{3}+0.065 \times C F_{4} \\
Q B E=1.441+0.125 \times C F\end{array}$} \\
\hline RM2 & \multicolumn{5}{|c|}{$\begin{array}{l}N B E=1.779+0.002 \times N B E_{1}+0.232 \times N B E_{2}+0.105 \times N B E_{3}+0.057 \times N B E_{4} \\
Q B E=1.909+0.095 \times N B E\end{array}$} \\
\hline
\end{tabular}

Each of multiple LRMs is statistically significant ( $\mathrm{p}$-value $<0.05$ ). The multi-collinearity is rejected for each partial model (RM1: $C F_{i}$ to $C F-$ VIF-value $=3.313$; RM2: $N B E_{i}$ to $N B E$ - VIF-value $\left.=2.674\right)$. The autocorrelation was rejected for each RMs (RM1: $\mathrm{D}-\mathrm{W}=1.957$; RM2: $\mathrm{D}-\mathrm{W}=2.039$ ). The normality of distributed errors was accepted for each RMs (RM1: S-W =0.310; RM2: $\mathrm{S}-\mathrm{W}=0.155)$. The regression models are statistically significant. The evaluation of null statistical hypotheses: RM1: the hypotheses NSH1b and NSH1d were not rejected, the hypotheses NSH1a and NSH1c were rejected; RM2: the hypotheses NSH2a and NSH2d were not rejected, the hypotheses NSH2b and $\mathrm{NSH} 2 \mathrm{c}$ were rejected. 
The assumption of normal distribution was accepted for CF and also NBE (CF: Skewness $=0.617$ and Kurtosis $=-0.856$; NBE: Skewness $=0.062$ and Kurtosis $=-0.251)$. The assumption of homoscedasticity was accepted for each independent variable (CF: Levene's t. = 1.821; NBE: Levene's t. = 1.769). The correlation between QBE and factors (CF, NBE) showed low strong values (CF: $\mathrm{CC}=0.301$; NBE: $\mathrm{CC}=0.218)$. Regression model with factors $(\mathrm{RM} 3)$ :

$$
Q B E=0.287+0.107 \times C F+0.036 \times N B E+\varepsilon_{t},
$$

where: $Q B E$ - the dependent variable (Quality of business environment); $\beta_{0}$ - constant; $\beta_{1}$, $\beta_{2}$ - coefficients of independent variables $(C F, F F)$; $C F, N B E$ - independent variables $(C F-$ competitive environment, $N B E$ - narrower business environment); $\varepsilon_{t}$ - error term.

The independent variables $(C F, N B E)$ are statistically significant (CF4: t-test (p-value) $=$ 7.53E-09, NBE: t-test ( $\mathrm{p}$-value $)=0.049)$. The $\mathrm{RM} 4$ is statistically significant $\left(\mathrm{R}=0.310 ; \mathrm{R}^{2}=\right.$ 0.096; Adj. $\mathrm{R}^{2}=0.093$; P-value of F-test $\left.=1.07 \mathrm{E}-14\right)$. The multicollinearity does not negatively affect the results of estimated regression coefficients (VIF not calculated, because RM3 has two independent variables). The normality of distributed errors was accepted for RM3 $(\mathrm{S}-\mathrm{W}$ test $=0.217)$. Homoscedasticity of errors was accepted for RM3 (Levene's t. $=1.461$ ). The hypotheses NSH3a and NSH3b were rejected. The knowledge about the riskiness of business risk creates the conditions, which are a basic prerequisite for the development and growth of the SME segment. Besides economic criteria, also non-economic criteria (educational, cultural, legislative factors) play an important role during this process (Buganova \& Moricova, 2017).

Significant indicators that affect the competitive environment include the adequacy of risk with the entry of new competitors into the business and acceptance of the prices of my products and services by customers. The acceptance of prices of my products and services by customers has a greater impact on the competitive environment. In this context, the results are consistent with the results of the case studies of Taçoğlu et al. (2019) and Belas and Gabcova (2016). These authors also place emphasis on customers, especially on communication with them. Important indicators that affect the narrower business environment include support for business customers and suppliers. The support of business customers has a greater impact on the narrower business environment. The importance of the above indicators of the narrower business environment is highlighted by Ahmedova (2015). The perception of corporate risk in the MS Enterprise segment significantly determines the competitive environment as well as the narrower corporate environment. The competitive environment has a greater impact on risk perception of business risk compared to a narrower business environment. These conclusions are in direct correlation with the results of the Yang et al. (2018) case study, who did not only underline the importance of a competitive environment but specified the need to introduce Enterprise Risk Management (ERM) into businesses. Significant indicators that influence the perception of the risk of business risk include the adequacy of risk with the entry of new competitors into the business, acceptance of prices of products and services by customers, support of the customers in the business. Indicators that do not affect the perception of corporate risk are the current level of competition in the industry; the threat of my current competitors in the business sector; intensive help to my employees in achieving 
business goals. In his research, Remi (2018) highlights the importance and quality of human resources. The results have not confirmed this importance of employees in achieving the business goals of enterprises in SMEs. The concept of competitiveness must be associated with the concept of sustainable development (Bilan et al., 2017). In the context of sustainable development and competitiveness, Ahmedova (2015) highlights five key factors for sustainable development and competitiveness: access to finance, innovation activities, intellectual property-related activities, internationalization and implementation of best practices. The state should play an important role in this process and help SMEs find new markets, help prepare a marketing strategy for new markets and educate entrepreneurs in international trade. Another proposal to increase enterprise competitiveness is offered by Malega et al. (2019). According to the authors, significant factors that can increase competitiveness at the enterprise level include the application of modern scientific methods in management and marketing, which will enable better work organization, more successful implementation of innovation, the higher performance of employees and ultimately better care of human capital. Ungerman et al. (2018) draw attention to the possibility for SMEs to increase their competitiveness by jumping to the Industry 4.0 trend. The authors state that their research has empirically confirmed that businesses consider the greatest impact of innovative marketing in the context of Industry 4.0 to be an increase in enterprise competitiveness. The use of new technologies in the marketing process represents another possibility to increase the competitiveness of SMEs. Konstantopoulou et al. (2019) state that the use of new technologies in various fields of SMEs operations is essential to achieve competitiveness. The authors emphasize the need for a strong e-commerce strategy. According to authors, social media enable SMEs to reach a large number of potential customers and stress that SMEs that can integrate social media into their marketing mix have a great opportunity to compete successfully with large companies because they can directly influence their customers' purchasing behaviour.

\section{Conclusions}

The aim of the article was to introduce new scientific knowledge in the field of researching the impact of significant competition factors on the riskiness of business risk in the SME sector. The authors found that the competitive environment, as well as the narrower business environment, affects the perception of enterprise risk in the business environment in the SME segment, on an empirical sample of 641 companies. It has also been shown that my customers accept the prices of my products and services. This is the most important indicator of a competitive environment. The most important indicator of a narrower business environment is that my customers support me in doing business.

The authors' awareness of the limits to study (e. g. local research - only two countries in middle Europe; the number of SMEs - 641 enterprises; use statistical methods - multiple linear regression modelling). The authors believe that the article has brought several interesting findings and new incentives for further research and discussion regarding the perception of enterprise risk not only in the selected countries this research. It is important also to note the fact that the riskiness of business risk is also affected by small and medium enterprises 
themselves. Their behaviour influences the perception of business risk by the public, but contrary to the perception of the position of the entrepreneurs in society significantly shapes the character, nature, and QBE.

Future research will the verification of the other factors which have positive or negative impact on the perception of enterprise risk (social, economic, financial, legal, political, operational, technological factors) and on their indicators in the segment of SMEs. The aim of the evaluation of factors is helping entrepreneurs to start a business and to identify key factors entrepreneurship in the CR and the SR.

\section{References}

Ahmedova, S. (2015). Factors for increasing the competitiveness of small and medium-sized enterprises (SMEs) in Bulgaria. Procedia - Social and Behavioral Sciences, 195, 1104-1112.

https://doi.org/10.1016/j.sbspro.2015.06.155

Arnold, S. F. (1980). Asymptotic validity of F tests for the ordinary linear model and the multiple correlation model. Journal of the American Statistical Association, 75(372), 890-894. https://doi.org/10.1080/01621459.1980.10477568

Artistovnik, A., \& Obadic, A. (2015). The impact and efficiency of public administrative excellence on fostering SMEs in the EU countries. Amfiteatru Economic, 17(39), 761-774.

Baños-Caballero, S., GarcíaTeruel, P. J., \& Martínez-Solano, P. (2016). Financing of working capital requirement, financial flexibility and SME performance. Journal of Business Economics and Management, 17(6), 1189-1204. https://doi.org/10.3846/16111699.2015.1081272

Belas, J., Dvorsky, J., Kubalek, L., \& Smrcka, L. (2018a). A comparison of the evaluation of financial risk among entrepreneurs according to their motives and a definition of factors influencing the intensity thereof in SMEs. Journal of International Studies, 11(1), 80-92. https://doi.org/10.14254/2071-8330.2018/11-1/6

Belas, J., Smrcka, L., Gavurova, B., \& Dvorsky, J. (2018b). The impact of social and economic factors in the credit risk management of SME. Technological and Economic Development of Economy, 24(3), 1215-1230. https://doi.org/10.3846/tede.2018.1968

Belas, J., \& Gabcova, L. (2016). The relationship among customer satisfaction, loyalty and financial performance of commercial banks. E+M Ekonomie a Management, 19(1), 132-147. https://doi.org/10.15240/tul/001/2016-1-010

Bilan, Y., Mishchuk, H., \& Pylypchuk, R. (2017). Towards sustainable economic development via social entrepreneurship. Journal of Security and Sustainability Issues, 6(4), 691-702. https://doi.org/10.9770/jssi.2017.6.4(13)

Bozic, L., \& Rajh, E. (2016). The factors constraining innovation performance of SMEs in Croatia. Economic Research - Ekonomska Istraživanja, 29(1), 314-324. https://doi.org/10.1080/1331677X.2016.1168040

Breslow, N. (1990). Tests of hypotheses in overdispersedpoisson regression and other quasi-likelihood models. Journal of the American Statistical Association, 85(410), 565-571. https://doi.org/10.1080/01621459.1990.10476236

Buganova, K., \& Moricova, V. (2017). Innovation of education in risk and crisis management. Turkish Online Journal of Educational Technology, 2017(November Special Issue INTE), 177-182.

Ceptureanu, S. I. (2015). Competitiveness of SMEs. Bussiness Excellence and Management, 5(2), 55-67.

Conorto, R., Dlhopolček, J., Kopečný, P., Maxin, R., Tonka, V., Tvrdoň, J., Vajdová, E., \& Vyšný, T. (2014). Analýza, monitor kvality podnikatel'ského prostredia v SR a konkurencieschopnost' ekonomiky. Federation of Employers' Associations of Slovak Republic, Bratislava, Slovakia. Retrieved 
February 2, 2020, from http://www.azzz.sk/wp-content/uploads/2015/05/Anal\%C3\%BDza-monitor-kvality-podnikate\%C4\%BEsk\%C3\%A9ho-prostredia-v-SR-a-konkurencieschopnos\%C5\%A5ekonomiky.pdf

Delić, A., Peterka, S. O., \& Kurtović, I. (2016). Is there a relationship between financial literacy, capital structure, and competitiveness of SMEs. EkonomskiVjesnik / Econviews, 29(1), 37-50.

Dragnic, D. (2014). Impact of internal and external factors on the performance of fast-growing small and medium businesses. Management: Journal of Contemporary Management Issues, 19(1), 119-159.

Dvorsky, J., Petrakova, Z., Khan, K. A., Formanek, I., \& Mikolas, Z. (2020). Selected aspects of strategic management in the service sector. Journal of Tourism and Services, 20(11), 109-123. https://doi.org/10.29036/jots.v11i20.146

Dvoulety, O., \& Orel, M. (2020). Determinants of solo and employer entrepreneurship in Visegrád countries: Findings from the Czech Republic, Hungary, Poland and Slovakia. Journal of Enterprising Communities, 14(3), 447-464. https://doi.org/10.1108/JEC-04-2020-0052

Falkner, E. M., \& Hiebl, M. R. W. (2015). Risk management in SMEs: a systematic review of available evidence. The Journal of Risk Finance, 16(2), 122-144. https://doi.org/10.1108/JRF-06-2014-0079

Gavurova, B., Huculova, E., Kubak, M., \& Cepel, M. (2017). The state of students' financial literacy in selected Slovak universities and its relationship with active pension savings. Economics and Sociology, 10(3), 206-219. https://doi.org/10.14254/2071-789X.2017/10-3/15

Grimsdottir, E., \& Edvardsson, I. R. (2018). Knowledge management, knowledge creation, and open innovation in icelandic SMEs. Sage Open, 8(4), 1-13. https://doi.org/10.1177/2158244018807320

Hudakova, M., Masar, M., Luskova, M., \& Patak, M. R. (2018). The dependence of perceived business risks on the size of SMEs. Journal of Competitiveness, 10(4), 54-69.

https://doi.org/10.7441/joc.2018.04.04

Hvolkova, L., Klement, L., Klementova, V., \& Kovalova, M. (2019). Barriers hindering innovations in small and medium-sized enterprises. Journal of Competitiveness, 11(2), 51-67.

https://doi.org/10.7441/joc.2019.02.04

Irwin, D., \& Scott, J. (2010). Barriers faced by SMEs in raising bank finance. International Journal of Entrepreneurial Behaviour \& Research, 16(3), 245-259. https://doi.org/10.1108/13552551011042816

Khan, K. A., Çera, G., \& Nétek, V. (2019). Perception of the selected business environment aspects by service firms. Journal of Tourism and Services, 10(19), 111-127. https://doi.org/10.29036/jots.v10i19.115

Kersten, R., Harms, J., Liket, K., \& Maas, K. (2017). Small firms, large impact? A systematic review of the SME finance. World Development, 97, 330-348. https://doi.org/10.1016/j.worlddev.2017.04.012

Kitching, J., Hart, M., \& Wilson, N. (2015). Burden of benefit? Regulation as a dynamic influence on small business performance. International Small Business Journal, 33(2), 130-147. https://doi.org/10.1177/0266242613493454

Khedhaouria, A., Nakara, W. A., Gharbi, S., \& Bahri, C. (2020). The relationship between organizational culture and small-firm performance: Entrepreneurial orientation as mediator. European Management Review, 17(2), 515-528. https://doi.org/10.1111/emre.12383

Ključnikov, A., Civelek, M., Čech, P., \& Kloudová, J. (2019). Entrepreneurial orientation of SMEs' executives in the comparative perspective for Czechia and Turkey. Oeconomia Copernicana, 10(4), 773-795. https://doi.org/10.24136/oc.2019.035

Kolupaieva, I., Pustovhar, S., Suprun, O., \& Shevchenko, O. (2019). Diagnostics of systemic risk impact on the enterprise capacity for financial risk neutralization: the case of Ukrainian metallurgical enterprises. Oeconomia Copernicana, 10(3), 471-491. https://doi.org/10.24136/oc.2019.023

Konstantopoulou, A., Rizomyliotis, I., Konstantoulaki, K., \& Badahdah, R. (2019). Improving SMEs competitiveness with the use of Instagram influencer advertising and eWOM. International Journal of Organizational Analysis, 27(2), 308-321. https://doi.org/10.1108/IJOA-04-2018-1406 
Kozubíková, L., Belás, J., Ključnikov, A., \& Virglerová, Z. (2015). Differences in approach to selected constructs of entrepreneurail orientation in SME segment regarding the selected socio-demographic factors. Transformation in Business nad Economic, 14(3C(36C)), 333-355.

Lazányi, K., Dvorský, J., Virglerova, Z., \& Dapkus, K. (2018). An analysis of factors related to "taking risks", according to selected socio-demographic factors. Acta Polytechnica Hungarica, 14(7), 35-50. https://doi.org/10.12700/APH.14.7.2017.7.3

Lewandowska, A., \& Stopa, M. (2019). Do SME's innovation strategies influence their effectiveness of innovation? Some evidence from the case of Podkarpackie as peripheral region in Poland. Equilibrium. Quarterly Journal of Economics and Economic Policy, 14(3), 521-536. https://doi.org/10.24136/eq.2019.025

Li, J., \& Valliant, R. (2011). Linear regression influence diagnostics for uncluttered survey data. Journal of Official Statistics, 27(1), 99-119.

Liňán, F., Paul, J., \& Fayolle, A. (2019). SMEs and entrepreneurship in the era of globalization: Advances and theoretical approaches. Small Business Economics, 55, 695-703. https://doi.org/10.1007/s11187-019-00180-7

Lumpkin, G. T., \& Dess, G. G. (1996). Clarifying the entrepreneurial orientation construct and linking it to performance. Academy of Management Review, 21(1), 137-172. https://doi.org/10.5465/amr.1996.9602161568

Mafini, C., \& Muposhi, A. (2017). Predictive analytics for supply chain collaboration, risk management and financial performance in small to medium enterprises. Southern African Business Review, 21, 311-338.

Malega, P., Rudy, V., Kovac, J., \& Kovac, J. (2019). The competitive market map as the basis for an evaluation of the competitiveness of the Slovak Republic on an international scale. Journal of Competitiveness, 11(4), 103-119. https://doi.org/10.7441/joc.2019.04.07

Mustafa, N., Nakov, L., \& Islami, X. (2019). The impact of organizational changes on increasing SMEs competitiveness. Acta Universitatis Danubius, 15(2), 93-114. https://doi.org/10.2139/ssrn.3351243

Nikolic, N., Jovanovic, I., Nikolic, D., Mihajlovic, I., \& Schulte, P. (2019). Investigation of the factors influencing SME failure as a function of its prevention and fast recovery after failure. Entrepreneurship Research Journal, 9(3), 1-21. https://doi.org/10.1515/erj-2017-0030

Pérez-Luño, A., Saparito, P., \& Gopalakrishnan, S. (2014). Small and medium-sized enterprise’s entrepreneurial versus market orientation and the creation of Tacit knowledge. Journal of Small Business Management, 54(1), 262-278. https://doi.org/10.1111/jsbm.12144

Pisar, P., \& Bilkova, D. (2019). Controlling as a tool for SME management with an emphasis on innovations in the context of Industry 4.0. Equilibrium. Quarterly Journal of Economics and Economic Policy, 14(4), 763-785. https://doi.org/10.24136/eq.2019.035

Qin, J., \& Lawless, J. (1995). Estimating equations, empirical likelihood and constraints on parameters. Canadian Journal of Statistics, 23(2), 145-159. https://doi.org/10.2307/3315441

Rahman, A., Rozsa, Z., \& Cepel, M. (2018). Trade credit and bank finance - evidence from the Visegrad group. Journal of Competitiveness, 10(3), 132-148. https://doi.org/10.7441/joc.2018.03.09

Rahman, A., Belas, J., Kliestik, T., \& Tyll, L. (2017). Collateral requirements for SME loans: Empirical evidence from the Visegrad countries. Journal of Business Economics and Management, 18(4), 650-675. https://doi.org/10.3846/16111699.2017.1357050

Ravselj, D., \& Aristovnik, A. (2018). Administrative barriers for SMEs in the field of tax compliance and financial and accounting reporting: Evidence from Slovenia. Management Issues - Problemy Zarzedzania, 16(1(73)), 75-90. https://doi.org/10.7172/1644-9584.73.5

Remi, S. (2018). Dimensionality of intra-organizational conflict and the challenges for human resource management in small and medium scale entrepreneurs in Nigeria. Journal of Competitiveness, 10(1), 125-143. https://doi.org/10.7441/joc.2018.01.08 
Rostamkalaei, A., \& Freel, M. (2015). The cost of growth: Small firms and the pricing of bank loans. Small Business Economics, 46(2), 255-272. https://doi.org/10.1007/s11187-015-9681-x

Singh, R. K., Garg, S. K., \& Deshmukh, S. G. (2010). The competitiveness of SMEs in a globalized economy: Observations from China and India. Management Research Review, 33(1), 54-65. https://doi.org/10.1108/01409171011011562

Sipa, M. (2017). Innovation as a key factors of small business competition. European Journal of Sustainable Development, 6(1). https://doi.org/10.14207/ejsd.2017.v6n1p344

Stewart, G. W. (1987). Collinearity and least squares regression. Statistical Science, 2(1), 68-84. https://doi.org/10.1214/ss/1177013439

Taçoğlu, C., Ceylan, C., \& Kazancoglu, Y. (2019). Analysis of variables affecting competitiveness of SMEs in the textile industry. Journal of Business Economics and Management, 20(4), 648-673. https://doi.org/10.3846/jbem.2019.9853

Toulová, M., Tuzová, M., \& Straka, J. (2016). The aspects of managing risks in connection with the internationalization of SMEs from selected Central European Countries. Acta Universitatis Agriculturae Et Silviculturae Mendelianae Brunensis, 64(5), 1775-1784. https://doi.org/10.11118/actaun201664051775

Ungerman, O., Dedkova, J., \& Gurinova, K. (2018). The impact of marketing innovation on the competitiveness of enterprises in the context of Industry 4.0. Journal of Competitiveness, 10(2), 132-148. https://doi.org/10.7441/joc.2018.02.09

Vargas-Hernández, J. G., Casas Cardenaz, R., \& Calderón Campos, P. (2016). Internal control and organizational culture in small businesses: A conjunction to competitiveness. Reuna, 21(2), 5-22. https://doi.org/10.21892/24627593.170

Virglerová, Z., Kozubíková, L., \& Vojtovič, S. (2016). Influence of selected factors on financial risk management in SMEs in the Czech Republic. Montenegrin Journal of Economics, 12(1), 21-36. https://doi.org/10.14254/1800-5845/2016.12-1.1

Werner, A., Schröder, C., \& Chlosta, S. (2017). Driving factors of innovation in family and non-family SMEs. Small Business Economics, 50(1), 201-218. https://doi.org/10.1007/s11187-017-9884-4

Yang, S., Ishtiaq, M., \& Anwar, M. (2018). Enterprise risk management practices and firm performance, the mediating role of competitive advantage and the moderating role of financial literacy. Journal of Risk and Financial Management, 11(3), 35. https://doi.org/10.3390/jrfm11030035 